\title{
Spatial and temporal distribution of the invasive lionfish Pterois volitans in coral reefs of Tayrona National Natural Park, Colombian Caribbean
}

The lionfish Pterois volitans is an invasive species throughout the Western Atlantic that disturbs functioning of local ecosystems such as coral reefs via fast and intense consumption of small fish and invertebrates. In 2009, lionfish populated the bays of Tayrona National Natural Park (TNNP), a biodiversity hotspot in the Colombian Caribbean that is strongly influenced by changing environmental conditions due to a rainy and dry season. So far, the spatial and temporal distribution of $P$. volitans in the bays of TNNP is unknown. Therefore, this study assessed the abundance and body lengths of $P$. volitans during monthly surveys throughout the year 2012 in four bays (thereof two bays where lionfish removals were undertaken) of TNNP at $10 \mathrm{~m}$ water depth in coral reefs using transect tools. Findings revealed lionfish abundances of $2.9 \pm 0.9$ individuals ha-1 with lengths of $20-25 \mathrm{~cm}$ for TNNP, hinting to an established, mostly adult local population. Actual TNNP lionfish abundances are thereby very similar to those at Indo-Pacific reef locations where the invasive lionfish formerly originated from. Significant spatial differences for lionfish abundances and body lengths between different bays in TNNP suggest habitat preferences of $P$. volitans depending on age. Lionfish abundances were highly variable over time, but without significant differences between seasons. Removals could not reduce lionfish abundances significantly during the period of study. This study therefore recommends improved management actions in order to control the already established invasive lionfish population in TNNP. 
1 Elisa Bayraktarov ${ }^{1, \dagger, *}$, Javier Alarcón-Moscoso ${ }^{2}$, Andrea Polanco F. ${ }^{2}$, Christian Wild ${ }^{1,3}$

$2{ }^{1}$ Coral Reef Ecology Group (CORE), Leibniz Center for Tropical Marine Ecology, Bremen,

3 Germany

$4 \quad{ }^{2}$ Instituto de Investigaciones Marinas y Costeras 'José Benito Vives de Andréis' (Invemar), Santa

5 Marta, Colombia

$6{ }^{3}$ Faculty of Biology and Chemistry (FB2), University of Bremen, Bremen, Germany

7 Present address: Global Change Institute, The University of Queensland, Brisbane, Australia

$8 *$ corresponding author, email: elisa.bayraktarov@uni-bremen.de 


\section{Introduction}

10 The Indo-Pacific lionfish Pterois volitans belongs to the family Scorpaenidae and is an invasive 11 marine fish that was introduced in the Western Atlantic during the 1980's (Whitfield et al. 2002; 12 Morris and Whitfield 2009; Schofield 2010; Albins and Hixon 2011; Arias-González et al. 2011). 13 Lionfish in invaded areas have many advantages over native fauna e.g. their generalist diet on a 14 variety of smaller fishes, shrimps and small mobile invertebrates (Morris and Akins 2009), 15 defensive venomous spines (Morris and Whitfield 2009; Albins and Hixon 2011), rapid growth 16 (Albins and Hixon 2011), low parasite load (Morris 2009), and habitat generality (Barbour et al. 17 2010; Albins and Hixon 2011). These characteristics make lionfish dramatically decrease local 18 populations in invaded areas (Albins and Hixon 2008; Arias-González et al. 2011) with strong 19 implications for the trophic web structures of the marine ecosystem (Mack et al. 2000). 20 Additional features of lionfish such as high fecundity (Morris 2009; Morris and Whitfield 2009), 21 effective larval dispersal mechanisms (Morris and Whitfield 2009), and efficient predation 22 (Albins and Hixon 2008; 2011; Côté and Maljković 2010) increase their probability of invasion 23 success.

24 In Colombia, lionfish arrived to the oceanic islands of San Andrés and Providencia in 2008 25 and invaded the entire continental coast of the country in the course of the following year. For the 26 Tayrona National Natural Park (TNNP; Fig. 1) in the northeast Colombian coast, the presence of 
P. volitans was first recorded in May - July 2009 at water depths between $12-20$ m over coral patches (González et al. 2009). In 2010, juvenile $P$. volitans (3-10 cm lengths) were observed in the mangrove ecosystem of Chengue Bay (Arbeláez and Acero P. 2011). The ecological consequences of lionfish are of particular interest for the TNNP area due to its major coastal biodiversity (Garzón-Ferreira and Cano 1991). The TNNP is a fishing restricted area administrated by the National Natural Parks of Colombia dealing with all territories of marine parks and reserves. Generally, the TNNP includes different coastal bays with complex structural bottoms offering heterogeneity of habitats suitable for a high marine biodiversity. A record diversity was reported especially for macroalgae (Bula-Meyer and Norris 2001; Diaz-Pulido and Garzón-Ferreira 2002; Diaz-Pulido and Díaz Ruiz 2003) but also for other marine organisms (e.g. mollusks; Díaz 1995; Diaz-Pulido 1998).

So far, little is known about the spatial and temporal distribution of lionfish in TNNP. Therefore, the aim of the present study was to assess monthly $P$. volitans abundances and estimated body lengths throughout one year (2012) for four bays within TNNP. The first objective was to compare lionfish data from TNNP with other invaded areas and also with its native locations in the Indo-Pacific. The second objective was to determine whether lionfish abundances change over time and if differences between a rainy and dry season, coinciding with a seasonal upwelling, exist. This objective focused on possible effects of strong seasonal variation in physicochemical parameters (temperature, salinity, wind, water currents, surplus of inorganic nutrients; Bayraktarov et al. 2013, 2014) during seasonal upwelling on lionfish distribution, as concluded for the factor temperature by the experimental study of Kimball et al. 2004 indicating ceased feeding of lionfish at $16^{\circ} \mathrm{C}$ with lethal consequences at $10^{\circ} \mathrm{C}$. The third objective addressed the efficiency of management actions (removals) that started in May 2012 in two TNNP bays by comparing lionfish abundances before removals with data collected after removals for two of the four bays. The present study provides recent and comprehensive lionfish distribution data and establishes an actual baseline with high temporal and spatial resolution for TNNP reefs in the Colombian Caribbean. Further needs of management actions to control the already established invasive lionfish population in TNNP are discussed.

\section{Materials and Methods}


All necessary permits were obtained for the described study by Instituto de Investigaciones Marinas y Costeras 'José Benito Vives de Andréis' (Invemar) in Santa Marta, Colombia which complied with all relevant regulations (decree \# 302 and \# 309).

The Tayrona National Natural Park (TNNP) is located at the northeastern coast of Colombia, between $11^{\circ} 17^{\prime}-11^{\circ} 22^{\prime} \mathrm{N}$ and $73^{\circ} 53^{\prime}-74^{\circ} 12^{\prime} \mathrm{W}$ (Fig. 1). The region contains a rocky coastline with capes, inlets and bays with sandy beaches covering over $40 \mathrm{~km}$ (Garzón-Ferreira and Cano 1991; Díaz et al. 2000; Martínez and Acosta 2005). The area of survey included the main TNNP bays Chengue, Gayraca, Neguanje, and Cinto (Fig. 1) which experience strong seasonal changes due to a rainy season ( $>80 \%$ of the annual rainfall, May to November) and a dry season (December to April) characterized by a seasonal upwelling with strong changes in temperature (decrease from 28 to $21^{\circ} \mathrm{C}$ ), salinity (increase from 33 to 38), increased wind and water currents (Salzwedel and Müller 1983; Mesa et al. 1997; Bayraktarov et al. 2013; 2014). Increased concentration of inorganic nutrients and chlorophyll $a$ during periods of upwelling (dry season) result in mesotrophic conditions, compared with oligotrophic settings during the non-upwelling periods (rainy season; Franco-Herrera et al. 2007; Arévalo-Martínez and Franco-Herrera 2008; Bayraktarov et al. 2014).

Coral reef formations can be found growing on both sides of each bay between water depths of 5 to 20 m (Werding and Erhardt 1976; Werding and Sánchez 1989; Garzón-Ferreira and Cano 1991) and represent a habitat for over 180 reef fish species (Olaya-Restrepo et al. 2008). Additionally, the bays harbor mangrove ecosystems and seagrass beds (Fig. 1; Garzón-Ferreira and Cano 1991).

\section{Lionfish assessment in space and time}

In order to address the goals of the study, P. volitans abundances were monitored monthly in four bays of TNNP. Surveys comprised monitoring along line transects of $50 \mathrm{~m}$ length and $5 \mathrm{~m}$ width in triplicates that were located at the western and at the eastern flank of each bay (Fig. 1) in order to encompass a representative area for lionfish distribution. Transects were located at water depths between 9 and $11 \mathrm{~m}$, parallel to the coastline, and were separated by $>5 \mathrm{~m}$ to ensure independence between samples. The investigated area covered $1500 \mathrm{~m}^{2}$ per bay and a total of $6000 \mathrm{~m}^{2}$ within the TNNP. The method of visual census was applied by SCUBA (English et al. 
1997; Lang et al. 2010). The total number of $P$. volitans observed during a time of 25 min per replicate was counted (Morris 2009). Places where lionfish may hide such as holes and cavities between rocks and coral framework were carefully examined. Estimated total body lengths (TL) of lionfish were recorded in situ in $5 \mathrm{~cm}$ intervals for each localized individual from the tip of the snout to the tip of the caudal fin. The surveys were performed between the second and the third week of each month, between 8:00 am. and 3:00 pm.

We were informed that lionfish removals were planned to start in May 2012 as a joint project between Universidad Nacional de Colombia, Universidad Jorge Tadeo Lozano, Universidad del Magdalena, Instituto de Investigaciones Marinas y Costeras 'José Benito Vives de Andréis' (Invemar) and the National Natural Parks of Colombia. Removals were performed monthly by spearing and netting at variable depths $(5-25 \mathrm{~m})$ by SCUBA diving, and to our knowledge, exclusively in the TNNP bays Chengue and Cinto. Additional unregistered removals of lionfish by dive centers or fishermen could not be considered in the present survey.

\section{Data analysis}

Mean monthly abundances of $P$. volitans in the TNNP bays Chengue, Gayraca, Neguanje and Cinto (Fig. 2a) were calculated from data collected over 12 months with a replication of 6 transects per bay and month and were converted into individuals per hectare (ind ha ${ }^{-1}$; Fig. 2a). Monthly abundance before onset of removals in May were estimated by calculating the abundance for the time period January to April, whereas lionfish data collected between May and December were used to determine the monthly mean abundance after removals (Fig. 2b). For calculation of the temporal lionfish distribution, all lionfish transect data were aggregated per month resulting in a replication of $n=24$ transects (Fig. 3a). Annual mean abundance was determined for each bay and the whole TNNP area by pooling the data collected over 12 months resulting in a transect replication of $n=69$ transects for Chengue and Neguanje, and $n=72$ for Gayraca and Cinto (total of 282 transects). Mean estimated sizes of lionfish (Fig. 3b) were calculated from total estimated body lengths of fishes observed along the transects in the respective bay.

Differences in $P$. volitans abundances between bays and months were tested by a Generalized Linear Model (GLM) for Poisson-distributed data and the software R (R Development Core 
115 Team 2008). Multiple comparisons between bays (Chengue, Gayraca, Neguanje and Cinto) and 116 months were performed by a Tukey's Honestly Significant Difference (HSD) post hoc test on 117 data before (January - April; 93 transects) and after onset of removal (May - December; 189 118 transects). For a quantification of possible removal effects, GLMs for Poisson-distributed data 119 and Tukey's HSD post hoc tests were performed before and after removal in the bays Chengue 120 and Cinto, individually.

\section{Results}

Throughout the year 2012, 123 individuals of Pterois volitans were counted during 12 months in four bays over a total monitored area of $6000 \mathrm{~m}^{2}$. Before removals, lowest mean lionfish abundance was found in Chengue Bay with $1.7 \pm 1.0$ ind ha ${ }^{-1}$ (monthly mean $\pm \mathrm{SE}$ for the months January - April), followed by Cinto with $2.5 \pm 0.3$, and Neguanje with $3.9 \pm 1.0$ ind ha $^{-1}$. Highest numbers of monthly lionfish were present in Gayraca with $5.8 \pm 3.6$ ind ha $^{-1}$. Significant differences in lionfish abundances during the months before removal were present between the bays Chengue and Gayraca (GLM, Tukey's HSD post hoc, $\mathrm{p}=0.033$ ) with higher lionfish abundance in Gayraca. After onset of monthly removal in May, lowest monthly lionfish abundance was observed in Neguanje with $0.8 \pm 0.5$ ind ha $^{-1}$, followed by Chengue with $1.3 \pm 0.6$ and Cinto with $3.9 \pm 2.0$ ind $\mathrm{ha}^{-1}$. Highest monthly lionfish abundance was still observed in Gayraca Bay with $4.4 \pm 1.7$ ind ha ${ }^{-1}$. After removal, significant differences were found between Chengue and Cinto $(\mathrm{p}=0.017)$, Chengue and Gayraca $(\mathrm{p}=0.004)$, Gayraca and Neguanje $(\mathrm{p}<$ $0.001)$ and Neguanje and Cinto $(\mathrm{p}=0.003)$.

Our monthly lionfish censuses demonstrated temporal and spatial variability in lionfish abundances among TNNP bays, which varied between 0 and 16.7 ind ha ${ }^{-1}$ (Fig. 2a). In Chengue (a removal bay), lionfish abundances were below 5 ind ha- (monthly mean \pm SE) until July and disappeared thereafter completely until December, where $1.1 \pm 1.1$ ind ha $^{-1}$ were registered. Highest abundances were observed in Gayraca during January with $16.7 \pm 10.3$ ind ha ${ }^{-1}$ and August with $12.2 \pm 4.6$ ind ha ${ }^{-1}$, while intermediate abundances were present during September 142 with $10.0 \pm 5.6$ ind ha $^{-1}$ and December with $7.8 \pm 6.5$ ind ha $^{-1}$ in this bay. In Neguanje, highest 
143 lionfish abundances were recorded in January with 5.6 \pm 5.6 ind ha $^{-1}$ and February with $5.6 \pm 3.6$ 144 ind $\mathrm{ha}^{-1}$. Here, no lionfish were observed between July and December, except for September 145 where $2.2 \pm 2.2$ ind ha $^{-1}$ were registered. In Cinto, lionfish abundances peaked during September 146 with $16.7 \pm 5.6$ ind ha ${ }^{-1}$ and June with $6.7 \pm 2.4$ ind $\mathrm{ha}^{-1}$, but were otherwise below 5 ind ha ${ }^{-1}$. 147 Mean lionfish abundance before removal was $10.0 \pm 5.8$ ind ha $^{-1}$ for Chengue, $35.0 \pm 21.8$ ind ha $^{-}$

$148{ }^{1}$ for Gayraca, $21.7 \pm 6.9$ ind $^{h^{-1}}$ for Neguanje, and $15.0 \pm 1.7$ ind ha $^{-1}$ for Cinto (Fig. 2b). 149 Lionfish abundance for the months during which removal actions were performed changed the 150 values to $5.0 \pm 3.3,28.3 \pm 9.8,5.0 \pm 2.7$, and $23.3 \pm 12.1$ ind ha ${ }^{-1}$, respectively (Fig. 2b).

151

\section{Temporal distribution of lionfish in TNNP}

On the temporal scale, highest abundance of lionfish was observed in September with $7.2 \pm 2.4$ ind $\mathrm{ha}^{-1}$ (monthly TNNP mean \pm SE; Fig. 3a) and January with $6.4 \pm 3.0$ ind ha ${ }^{-1}$; lowest during November with $0.3 \pm 0.3$ ind $\mathrm{ha}^{-1}$ and July with $0.8 \pm 0.6$ individuals $\mathrm{ha}^{-1}$ ind $\mathrm{ha}^{-1}$. Significant differences between months were present between September and April (GLM, Tukey's HSD post hoc, $\mathrm{p}=0.05)$, July and January $(\mathrm{p}=0.04)$, September and July $(\mathrm{p}=0.02)$, September and May $(\mathrm{p}=0.03)$, and between September and October $(\mathrm{p}=0.03)$. However, lionfish abundances were not significantly different between rainy (May - November) and dry season (December April).

Largest estimated lionfish body lengths of $40 \mathrm{~cm}$ were registered for Cinto in January and August, and Neguanje in September (Fig. 3b). Largest body lengths were present in Gayraca and Cinto with mean sizes of $20-25 \mathrm{~cm}$, followed by Neguanje with $15-20 \mathrm{~cm}$, and smallest in Chengue with $10-15 \mathrm{~cm}$. A total of $75 \%$ of all lionfish observed had a body length larger than $17.5 \mathrm{~cm}$ TL $(20-25 \mathrm{~cm})$ representing the size of $50 \%$ maturity for females (Morris 2009). Before removal, mature lionfish accounted for $80 \%$ and $72 \%$ after initiation of removal efforts. Adults were distributed as $13 \%$ in Chengue, $51 \%$ in Gayraca, $21 \%$ in Neguanje, and $15 \%$ in Cinto before removal which changed to $4 \%, 49 \%, 8 \%$, and $40 \%$ after removal, respectively. 
168

169

170

171

172

173

174

175

176

177

178

The effect of fish removal

Individual GLM analyses showed no significant differences in lionfish abundance before (January - April) and after removal (May - December) for both removal bays, Chengue (GLM, Tukey's HSD post hoc, $\mathrm{p}=0.53)$ and Cinto $(\mathrm{p}=0.25)$. Since no significant differences were observed before and after removal, transect data were pooled to calculate an annual mean of $2.9 \pm$ 0.9 ind ha ${ }^{-1}$ (annual mean \pm SE) for the TNNP region. The annual mean for Chengue was $1.4 \pm$ 1.3 ind ha ${ }^{-1}, 4.9 \pm 1.3$ ind ha ${ }^{-1}$ for Gayraca, $1.8 \pm 0.6$ ind ha $^{-1}$ for Neguanje, and $3.4 \pm 0.8$ ind ha ${ }^{-1}$ for Cinto, respectively (Table 1).

\section{Discussion}

\section{Spatial and temporal distribution of P. volitans}

Our data on $P$. volitans distribution in Tayrona National Natural Park (TNNP; Colombian Caribbean) show that a local population with mean body length of $20-25 \mathrm{~cm}$ has developed in the bays Chengue, Gayraca, Neguanje and Cinto. These lionfish total body lengths (TL) hint to a population mostly dominated by adult fishes that are able to sexually reproduce, based on Morris (2009) who reported $17.5 \mathrm{~cm}$ TL as the size of $50 \%$ maturity for females.

With an annual mean of 2.9 ind ha $^{-1}$, lionfish abundance in TNNP was similar to some locations in the Indo-Pacific where it originated from, e.g. Palau Archipelago with 2.2 ind ha ${ }^{-1}$ (Grubich et al. 2009), but below $~ 80$ ind ha ${ }^{-1}$ reported for the Gulf of Aqaba/ Red Sea (Fishelson 1997). Table 1 shows a comparison of lionfish abundance in TNNP to other invaded and native habitats worldwide, however data should be considered as estimates as methods of monitoring were not always comparable (e.g. rotenone-sampling over small areas; Fishelson 1997). Lionfish abundances in TNNP were below the values reported for other invaded areas of the Western Atlantic such as the Bahamas with 393 (Green and Côté 2009) or the coast of North Carolina/ USA with 150 ind ha ${ }^{-1}$ (Morris and Whitfield 2009) which may be due to the relatively recent invasion of TNNP in 2009 (González et al. 2009) vs. an invasion of the Bahamas in 2004 (Schofield 2009). High abundances of lionfish in invaded areas are likely the result of unrestricted growth and reproduction due to the availability of food sources and lack of natural 
195

196

197

198

199

200

201

202

203

204

205

206

207

208

209

210

211

212

213

214

215

216

217

218

219

predators. Some predators obviously learned to target lionfish as potential prey (Bernadsky and Goulet 1991; Maljković et al. 2008). So far, two Caribbean large-bodied grouper species, Epinephelus striatus and Mycteroperca tigris, were captured with lionfish in their stomach contents (Maljković et al. 2008). However, E. striatus is one of the species categorized as endangered in the Colombian Caribbean red list of marine fishes (Mejía and Acero P. 2002). Mumby et al. (2011) presented data on the reduction of lionfish biomass by groupers which may thus serve as natural biocontrol of growing lionfish populations. However, the lack of these natural lionfish predators in TNNP (Olaya-Restrepo et al. 2008) and the wider Caribbean (Sadovy 2005) is alarming. In contrast to Mumby et al. (2011), the study of Hackerott et al. (2013) concluded that the abundance of lionfish was not influenced by interaction with native predators in 71 reefs and different biogeographic regions in the Caribbean. The hypothesis of groupers as natural biocontrol against invasive lionfish is currently a subject of active debate (Bruno et al. 2013, Green et al. (in press), Mumby et al. 2013). These conflicting results once more stress the necessity of immediate and improved management actions to control further lionfish reproduction and invasion.

Our monthly $P$. volitans distribution data over four bays in TNNP showed no seasonal pattern between a rainy and a dry season, characterized by seasonal upwelling and the consequently altered environmental conditions (temperature, salinity, water currents, and surplus of inorganic nutrients; Salzwedel and Müller 1983; Bayraktarov et al. 2013; 2014) did not appear to affect the abundance of lionfish in TNNP. An effect of seawater temperature decrease from 28 to $21{ }^{\circ} \mathrm{C}$ (Bayraktarov et al. 2014) on lionfish distribution within the area could not be detected. This finding is supported by the laboratory study by Kimball et al. 2004 showing that the critical temperature at which lionfish ceases feeding was $16^{\circ} \mathrm{C}$ with lethal consequences at $10{ }^{\circ} \mathrm{C}$, which is more than $10{ }^{\circ} \mathrm{C}$ lower that the coldest temperature so far reported for the TNNP upwelling region $\left(20^{\circ} \mathrm{C}\right.$, Bayraktarov et al. 2014).

Effect of lionfish removal

221 Abundances and body lengths of $P$. volitans for Chengue Bay, in which removals were 222 performed, were smaller than for the uncontrolled Gayraca and Neguanje. However, removals 223 could not effectively reduce lionfish abundances in Cinto which were lower than abundances in 224 Gayraca but higher than in Neguanje. Body lengths found in Cinto corresponded to those in 
225 Gayraca. The smallest body lengths observed in Chengue indicate that a mostly juvenile 226 population may have developed in this bay and thereby may indicate a habitat preference 227 dependent on age. However, it cannot be excluded that the smaller body lengths of lionfish in 228 Chengue are a consequence of removal during management actions targeting predominantly 229 larger adult individuals which are easier to observe and catch. Smaller juveniles may hide 230 between the roots of mangroves (Arbeláez and Acero P. 2011) or in crevices and holes of the reef 231 framework which are especially extensive for Chengue Bay (personal observation). Additionally, 232 Chengue Bay comprises a highly developed mangrove ecosystem (Garzón-Ferreira and Cano 233 1991) which may serve as nursery for lionfish larvae and juveniles. This is further supported by 234 the study of Arbeláez and Acero P. (2011), who found lionfish juveniles of $3-10 \mathrm{~cm}$ lengths at 235 the submerged roots of the mangroves bordering the entrance to the southern lagoon in Chengue 236 Bay.

Factors affecting fish populations that cannot be excluded are the differences in coral reef 238 complexity between the bays and the potential food sources for lionfish. These important points need to be addressed in further studies.

240 Our study suggests that management actions for the TNNP require further improvement in terms of removal frequencies and a larger removal area in order to significantly reduce the established lionfish population. Targeted removals were shown to represent a viable strategy in reducing the direct impacts of invasive lionfish on marine ecosystems (Frazer et al. 2012). Frazer et al. (2012) further suggest that management actions should involve long-term monitoring of lionfish distribution, data on recruitment, growth, and reproduction as well as studies on the direct and indirect effects by invasive lionfish on other fish assemblages. The implementation and improvement of management actions in order to preserve the condition of TNNP coral reef ecosystems during $P$. volitans invasion are crucially essential. The national plan to control and manage lionfish invasion in Colombia is focused on three focal strategy points: 1.) realization of fundamental research, 2.) implementation of management actions and 3.) focus on education and control (MADS et al. 2013). Whereas the first two points are addressed by research groups of universities and institutes, the third point is coordinated by the National Natural Parks of Colombia dealing with all territories of marine parks and reserves. The removal of lionfish outside the marine parks territories lies in the hands of regional environmental officers confronted by an environmental and societal challenge. 
257 Considering the national plan to control and manage lionfish invasion, potential management 258 actions required for the Colombian Caribbean region may further focus on raising the 259 community's awareness by introducing the lionfish problem and the consequences of its invasion. 260 Removals on a wider scale can be promoted by consumption of lionfish on a local and commercial scale. Public outreach should focus especially on lionfish as a good candidate for human nutrition. Morris et al. 2011 reported a relatively high content of lionfish fillet yield (30.5 \%) comparable to groupers, graysbys, and coneys. Lionfish meat had also higher content of essential n-3 fatty acids and a relatively low amount of saturated fatty acids as compared to other marine reef fish species (e.g. red snapper, dolphinfish, blue fin tuna, triggerfish, grouper and tilapia; Morris et al. 2011). The authors suggested that public outreach should especially focus on education about lionfish invasion, handling and cleaning of $P$. volitans in order to minimize risks for envenomation (Morris et al. 2011).

The establishment of marine reserves can effectively protect larger fishes (Halpern 2003) such as groupers that could prey on lionfish as reported for the fishing-restricted Exuma Cays Land and Sea Park / Bahamas by Mumby et al. 2011. As long as it is not clear whether native predators are able to effectively prey on lionfish, further controlled fishing restrictions especially on native apex predator populations will become imperative for lionfish invasion control.

The invasion of $P$. volitans in the Western Atlantic and the Caribbean is considered as one of the top global threats to conservation of biodiversity (Sutherland et al. 2010). Local lionfish populations may disturb functioning of coral reefs through high consumption of small herbivorous fishes, including parrotfishes (Albins and Hixon, 2008; Morris and Akins 2009), thus

278 indirectly promote the outcompeting of corals by naturally uncontrolled growth of seaweeds 279 (Mumby et al. 2006; Mumby and Steneck 2008; Lesser and Slattery 2011). Under the combined 280 effects of overfishing, lionfish invasion (Albins and Hixon 2011), global climate change (HoeghGuldberg et al. 2011), and local environmental degradations, the future of coral ecosystems is severely endangered (Jackson 2010) in the Western Atlantic and Caribbean. 
284 We acknowledge Juan F. Lazarus-Agudélo, Corvin Eidens, Christian M. Díaz-Sanchez, Johanna 285 C. Vega-Sequeda, and particularly Julian Rau for SCUBA diving and assistance during the field 286 trips. We thank the staff of Instituto de Investigaciones Marinas y Costeras 'José Benito Vives de 287 Andréis' (Invemar) in Santa Marta, Colombia, especially Diana I. Gómez-López and Carolina 288 Jaramillo-Carvajal for organizational support. We acknowledge the administration of the Tayrona 289 National Natural Park for the kind collaboration.

290

291

\section{References}

Albins MA, Hixon MA (2008) Invasive Indo-Pacific lionfish Pterois volitans reduce recruitment of Atlantic coral-reef fishes. Marine Ecology Progress Series 367: 233-238.

Albins MA, Hixon MA (2011) Worst case scenario: potential long-term effects of invasive predatory lionfish (Pterois volitans) on Atlantic and Caribbean coral-reef communities. Environmental Biology of Fishes, doi:10.1007/s10641-011-9795-1.

Andrade CA, Barton ED (2005) The Guajira upwelling system. Continental Shelf Research 25(9): 1003-1022.

Arbeláez M, Acero P. A (2011) Ocurrence of the lionfish Pterois volitans (Linnaeus) in the mangrove of Bahía de Chengue, Colombian Caribbean. Boletín de Investigaciones Marinas y Costeras - Invemar 40(2): 431-435.

Arévalo-Martínez D, Franco-Herrera A (2008) Características oceanográficas de la surgencia frente a la Ensenada de Gaira, departamento del Magdalena, época seca menor de 2006 [Oceanographic features of the upwelling in front of Gaira's inlet, Magdalena department, minor dry season of 2006]. Boletín de Investigaciones Marinas y Costeras - Invemar 37(2): 131-162.

Arias-González JE, González-Gándara C, Luis Cabrera J, Christensen V (2011) Predicted impact of the invasive lionfish Pterois volitans on the food web of a Caribbean coral reef. Environmental Research 111(7): 917-925.

Barbour AB, Montgomery ML, Adamson AA, Díaz-Ferguson E, Silliman BR (2010) Mangrove use by the invasive lionfish Pterois volitans. Marine Ecology Progress Series 401: 291-294.

Bayraktarov E, Pizarro V, Eidens C, Wilke T, Wild C (2013) Bleaching susceptibility and recovery of Colombian Caribbean corals in response to water current exposure and seasonal upwelling. PLoS ONE 8(11): e80536.

Bayraktarov E, Pizarro V, Wild C (2014) Spatial and temporal variability of water quality in coral reefs of Tayrona National Natural Park, Colombian Caribbean. Environmental Monitoring and Assessment: doi 10.1007/s10661-014-3647-3. 
Bernadsky G, Goulet D (1991) A natural predator of the lionfish Pterois miles. Copeia 1991:230231.

Betancur-R R, Hines A, Acero P. A, Ortí G, Wilbur AE, Freshwater DW (2011) Reconstructing the lionfish invasion: insights into Greater Caribbean biogeography. Journal of Biogeography 38(7): 1281-1293.

Bruno JF, Valdivia A, Hackerott S, Cox CE, Green S, Côté IM, Akins L, Layman CA, Precht WF (2013) Testing the grouper biocontrol hypothesis: A response to Mumby et al. 2013. PeerJ PrePrints 1:e139v1. http://dx.doi.org/10.7287/peerj.preprints.139v1.

Bula-Meyer G and Norris JN (2001) Notes on new records of red algae from the Colombian Caribbean. Botanica Marina 44: 351-360.

Côté IM, Maljković A (2010) Predation rates of Indo-Pacific lionfish on Bahamian coral reefs. Marine Ecology Progress Series 404: 219-225.

Díaz JM (1995) Zoogeography of marine gastropod in the Southern Caribbean: a new look at provinciality. Caribbean Journal of Science 31: 104-121.

Díaz JM, Barrios LM, Cendales MH, Garzón-Ferreira J, Geister J, López-Victoria M, Ospina GH, Parra-Velandia F, Pinzón J, Vargas-Angel B, Zapata FA, Zea SE (2000) Áreas Coralinas de Colombia [Coral areas in Colombia]. Santa Marta, Colombia, Instituto de Investigaciones Marinas y Costeras “José Benito Vives de Andreis” (Invemar): pp. 17-167.

Diaz-Pulido G (1998) Ecosistemas marinos y costeros. In Chaves ME and Arango N (Eds.), Informe nacional sobre la biodiversidad en Colombia, 1997. Bogotá: Institudo de Investigación de Recursos Biológicos Alexander von Humboldt, PNUMA, Ministerio del Medio Ambiente: pp. 228-314.

Diaz-Pulido G and Garzón-Ferreira J (2002) Seasonality in algal assemblages on upwellinginfluenced coral reefs in the Colombian Caribbean. Botanica Marina 45(3): 284-292.

Diaz Pulido G and Díaz Ruiz M (2003) Diversity of benthic marine algae of the Colombian Atlantic. Biota Colombiana 4(2): 203-246.

English C, Wilkinson C, Baker V (eds) (1997) Survey manual for tropical marine resources, 2nd edn. Townsville, Australia: Autralian Institute of Marine Science, $196 \mathrm{pp}$.

Fishelson L (1997) Experiments and observations on food consumption, growth and starvation in Dendrochirus brachypterus and Pterois volitans (Pteroinae, Scorpaenidae). Environmental Biology of Fishes 50: 391-403.

Franco-Herrera A, Árevalo-Martínez D, Cepeda-Mercado A, Torres-Sierra E, Sanjuan-Muñoz A (2007) La surgencia costera del Caribe suroriental: ¿un sistema oligotrófico o mesotrófico? [The coastal upwelling of the Southeastern Caribbean - an oligotrophic or mesotrophic system?] XII Congresso Latino-Americano de Ciencias do Mar.

Frazer TK, Jacoby CA, Edwards MA, Barry SC, Manfrino CM (2012) Coping with the lionfish invasion: can targeted removals yield beneficial effects? Reviews in Fisheries Science 20(4): 185-191.

Garzón-Ferreira J, Cano M (1991) Tipos, Distribución, Extensión y Estado de Conservación de los Ecosistemas Marinos Costeros del Parque Nacional Natural Tayrona [Types, distribution, 
extention and conservational state of the marine coastal ecosystems in Tayrona National Natural Park]. Santa Marta, Colombia, 82 pp.

González J, Grijalba-Bendeck M, Acero P. A, Betancur-R. R (2009) The invasive red lionfish, Pterois volitans (Linnaeus 1758), in the southwestern Caribbean Sea. Aquatic Invasions 4: 507-510.

Green SJ, Côté IM (2009) Record densities of Indo-Pacific lionfish on Bahamian coral reefs. Coral Reefs 28(1): 107-107.

Green SJ, Dulvy NK, Brooks ALM, Akins JL, Cooper AB, Miller S, Côté IM (in press) Linking removal targets to the ecological effects of invaders: a predictive model and field test. Ecological Applications. http://dx.doi.org/10.1890/13-0979.1.

Grubich JR, Westneat MW, McCord CL (2009) Diversity of lionfishes (Pisces: Scorpaenidae) among remote coral reefs of the Palau Archipelago. Coral Reefs 28(3): 807-807.

Hackerott S, Valdivia A, Green SJ, Côté IM, Cox CE, Akins L, Layman CA, Precht WF, Bruno JF (2013) Native predators do not influence invasion success of pacific lionfish on Caribbean reefs. PLoS ONE 8(7): e68259. doi:10.1371/journal.pone.0068259.

Halpern BS (2003) The impact of marine reserves: do reserves work and does reserve size matter? Ecological Applications 13: S117-S137.

Hare JA, Whitfield PE (2003) An integrated assessment of the introduction of lionfish (Pterois volitans/miles complex) to the western Atlantic Ocean. NOAA Technical Memorandum NOS NCCOS 2: 1-21.

Hoegh-Guldberg O, Ortiz JC, Dove S (2011) The future of coral reefs. Science 334 (6062): 14941495.

Invemar (2014) Sistema de Información Ambiental Marina de Colombia - SIAM. Servicio Acceso a Datos del Instituto de Investigaciones Marinas y Costeras 'José Benito Vives de Andréis' (Invemar). Santa Marta, Colombia.

Jackson J (2010) The future of the oceans past. Philosophical transactions of the Royal Society of London. Series B, Biological sciences 365(1558): 3765-3778.

Kimball ME, Miller JM, Whitfield PE, Hare JA (2004) Thermal tolerance and potential distribution of invasive lionfish(Pterois volitans/miles complex) on the east coast of the United States. Marine Ecology Progress Series 283: 269-278.

Lang JC, Marks KW, Kramer PA, Kramer PR, Ginsburg RN (2010) AGRRA protocols version 5.4. Atlantic and Gulf Rapid Reef Assessment Program. Florida, USA.

Lesser MP, Slattery M (2011) Phase shift to algal dominated communities at mesophotic depths associated with lionfish (Pterois volitans) invasion on a Bahamian coral reef. Biological Invasions 13(8), 1855-1868.

Mack RN, Simberloff D, Lonsdale WM, Evans H, Clout M, Bazzaz FA (2000) Biotic invasions: causes, epidemiology, global consequences, and control. Ecological Applications 10(3): 689-710.

Maljković A, Leeuwen TE, Cove SN (2008) Predation on the invasive red lionfish, Pterois volitans (Pisces: Scorpaenidae), by native groupers in the Bahamas. Coral Reefs 27(3): 501501. 
Martínez S, Acosta A (2005) Cambio temporal en la estructura de la comunidad coralina del área de Santa Marta - Parque Nacional Natural Tayrona (Caribe Colombiano) [Temporal change in the coral community structure in the Santa Marta area - Tayrona National Natural Park (Colombian Caribbean)]. Boletín de Investigaciones Marinas y Costeras - Invemar 34(1): 161-191.

Mesa O, Poveda G, Carvajal LF (1997) Introducción al Clima de Colombia [Introduction of the climate in Colombia]. Universidad Nacional de Colombia, Medellín, Colombia, 390 pp.

Morris JA, Akins JL (2009) Feeding ecology of invasive lionfish (Pterois volitans) in the Bahamian archipelago. Environmental Biology of Fishes 86(3): 389-398.

Morris JA Jr (2009) The biology and ecology of invasive Indo-Pacific lionfish. PhD Thesis, North Carolina State University, USA, 168 pp.

Morris JA Jr, Whitfield PE (2009) Biology, ecology, control and management of the invasive Indo-Pacific lionfish: An updated integrated assessment. NOAA Technical Memorandum NOS NCCOS 99, 57 pp.

Mumby PJ, Dahlgren CP, Harborne AR, Kappel CV, Micheli F, Brumbaugh DR, Holmes KE, Mendes JM, Broad K, Sanchirico JN, Buch K, Box S, Stoffle RW, Gill AB (2006) Fishing, trophic cascades, and the process of grazing on coral reefs. Science 311(5757): 98-101.

Mumby PJ, Steneck RS (2008) Coral reef management and conservation in light of rapidly evolving ecological paradigms. Trends in ecology \& evolution 23(10): 555-563.

Mumby PJ, Harborne AR, Brumbaugh DR (2011) Grouper as a natural biocontrol of invasive lionfish. PLoS ONE 6(6): e21510. doi:10.1371/journal.pone.0021510.

Mumby PJ, Brumbaugh DR, Harborne AR, Roff G (2013) On the relationship between native grouper and invasive lionfish in the Caribbean. PeerJ PrePrints 1:e45v1. http://dx.doi.org/10.7287/peerj.preprints.45v1.

Olaya-Restrepo J, Reyes-Nivia MC, Rodríguez-Ramírez A (2008) Ensamblajes de peces arrecifales del área de Santa Marta y el Parque Nacional Natural Tayrona [Reef fish assemblages in Santa Marta area and Tayrona National Natural Park]. Boletín de Investigaciones Marinas y Costeras - Invemar 37(1): 111-127.

Paramo J, Correa M, Núñez S (2011) Evidencias de desacople físico-biológico en el sistema de surgencia en La Guajira, Caribe colombiano [Evidence of physical-biological mismatch in the Guajira upwelling system, Colombian Caribbean]. Revista de biología marina $y$ oceanografía 46(3): 421-430.

R Development Core Team. (2008). R: A language and environment for statistical computing. R Foundation for Statistical Computing,Vienna, Austria.

Ruiz-Carus R, Matheson RE, Roberts DE, Whitfield PE (2006) The western Pacific red lionfish, Pterois volitans (Scorpaenidae), in Florida: Evidence for reproduction and parasitism in the first exotic marine fish established in state waters. Biological Conservation 128(3): 384390.

Sadovy Y (2005) Trouble on the reef: the imperative for managing vulnerable and valuable fisheries. Fish and Fisheries 6(3): 167-185. 
438

439

440

441

442

443

444

445

446

447

448

449

450

451

452

453

454

455

456

457

458

459

460

461

462

463

464

465

466

467

468

469

470

471

472
Salzwedel H, Müller K (1983) A summary of meteorological and hydrological data from the bay of Santa Marta, Colombian Caribbean. Anales del Instituto de Investigaciones Marinas de Punta de Betín 13: $67-83$.

Schofield PJ (2010) Update on geographic spread of invasive lionfishes (Pterois volitans [Linnaeus, 1758] and P. miles [Bennett, 1828]) in the Western North Atlantic Ocean, Caribbean Sea and Gulf of Mexico. Aquatic Invasions 5(Supplement 1): S117-S122.

Schofield PJ (2009) Geographic extent and chronology of the invasion of non-native lionfish (Pterois volitans [Linnaeus 1758] and P. miles [Bennett 1828]) in the Western North Atlantic and Caribbean Sea. Aquatic Invasions 4(3): 473-479.

Schüttler E, Karez CS (eds) (2008) Especies exóticas invasoras en las Reservas de Biosfera de América Latina y el Caribe. Un informe técnico para fomentar el intercambio de experiencias entre las Reservas de Biosfera y promover el manejo efectivo de las invasiones biológicas. UNESCO, Montevideo.

Semmens BX, Buhle ER, Salomon AK, Pattengill-Semmens CV (2004) A hotspot of non-native marine fishes: evidence for the aquarium trade as an invasion pathway. Marine Ecology Progress Series 266: 239 - 244.

Skelhorn J, Rowland HM, Speed MP, Ruxton GD (2010) Masquerade: camouflage without crypsis. Science 327(5961): 51.

Sutherland WJ, Clout M, Côté IM, Daszak P, Depledge MH, Fellman L, Fleishman E, Garthwaite R, Gibbons DW, De Lurio J, Impey AJ, Lickorish F, Lindenmayer D, Madgwick J, Margerison C, Maynard T, Peck LS, Pretty J, Prior S, Redford KH, Scharlemann JPW, Spalding M, Watkinson AR (2010) A horizon scan of global conservation issues for 2010. Trends in ecology \& evolution 25(1): 1-7.

Werding B, Erhardt H (1976) Los corales (Anthozoa y Hydrozoa) de la Bahía de Chengue en el Parque Nacional Tayrona (Colombia) [Corals (Anthozoa and Hydrozoa) of Chengue Bay in Tayrona National Park (Colombia)]. Mitteilungen aus dem Instituto Colombo-Alemán de Investigaciones Cientificas Punta de Betín 8: 45-57.

Werding B, Sánchez H (1989) The coral formations and their distributional pattern along a wave exposure gradient in the area of Santa Marta, Colombia. Medio Ambiente 10(2): 61-68.

Whitfield PE, Gardner T, Vives SP, Gilligan MR, Courtenay WR, Ray GC, Hare JA (2002) Biological invasion of the Indo-Pacific lionfish Pterois volitans along the Atlantic coast of North America. Marine Ecology Progress Series 235: 289-297.

Whitfield PE, Hare JA, David AW, Harter SL, Muñoz RC, Addison CM (2007) Abundance estimates of the Indo-Pacific lionfish Pterois volitans/miles complex in the Western North Atlantic. Biological Invasions 9(1): 53-64. 


\section{Figure 1}

Area of survey in the Tayrona National Natural Park (TNNP).

The points indicate the sampling locations at the western and eastern flank of each bay. Source: Invemar 2014.

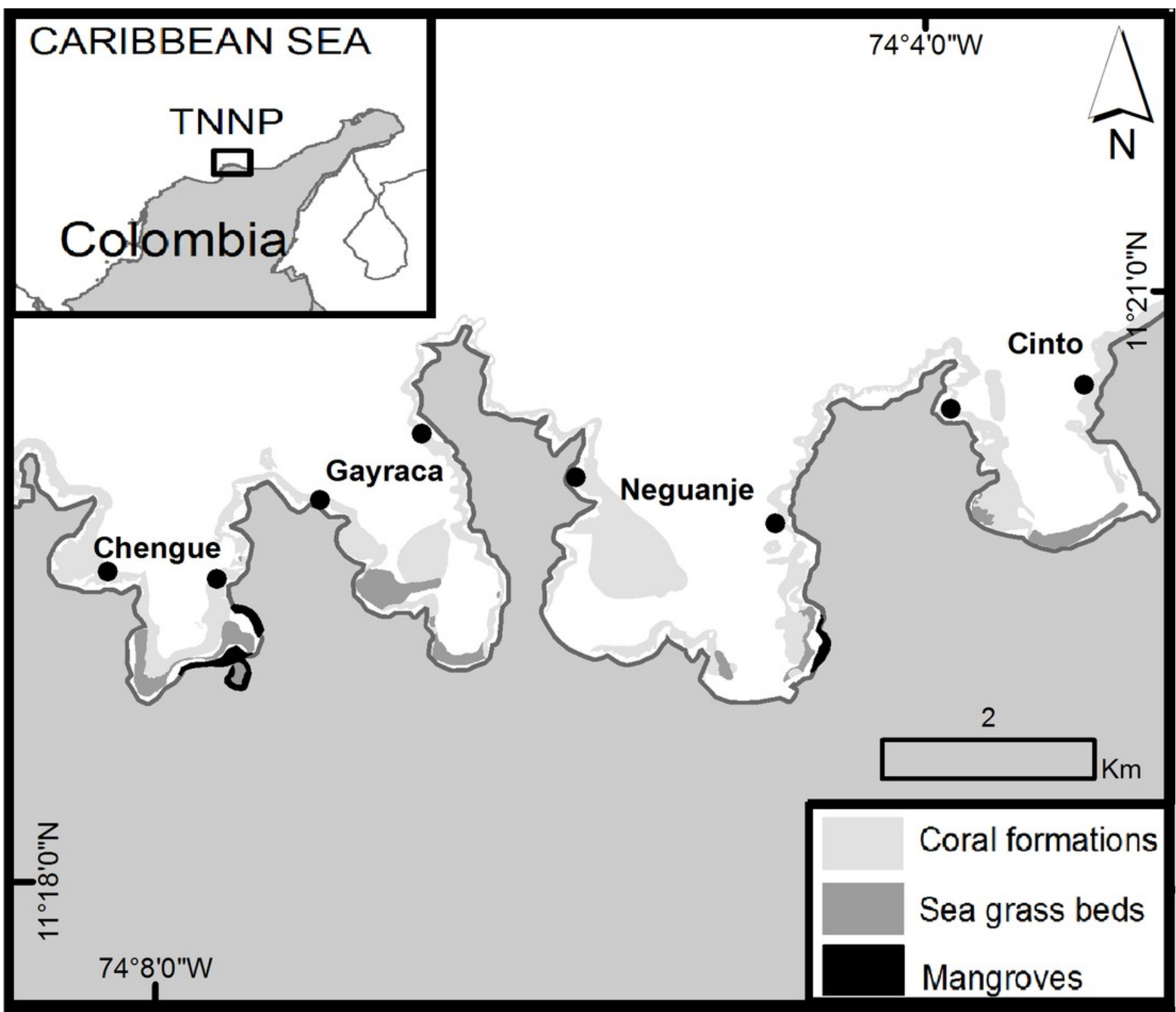




\section{Figure 2}

Lionfish abundances in Tayrona National Natural Park before and after removal.

A) Abundances (monthly mean $\pm \mathrm{SE}$ ) of Pterois volitans in the bays Chengue, Gayraca, Neguanje and Cinto throughout the months of 2012. The red line indicates the starting period of monthly removals (May 2012) from the bays Chengue and Cinto. Removal bays (Chengue and Cinto) are indicated by solid symbols, while non-removal bays have open symbols. B) Mean lionfish abundances (+ SE) before (January - April) and after removal (May December). Abbreviations: Chengue (Ch), Gayraca (Ga), Neguanje (Ne), and Cinto (Ci).
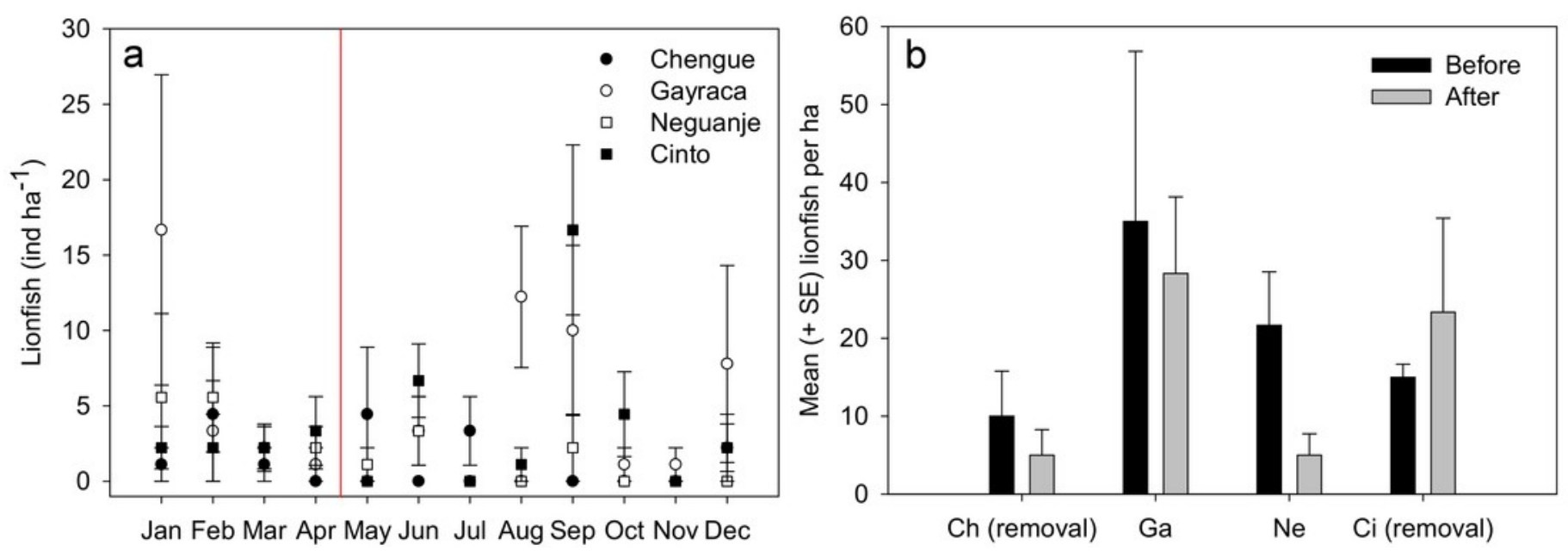


\section{Figure 3}

Monthly abundances of Pterois volitans.

A) Monthly mean \pm SE; aggregate of four bays for Tayrona National Natural Park and B) estimated body lengths for the bays Chengue, Gayraca, Neguanje, and Cinto. Missing error bars represent sample sizes which did not allow the calculation of a mean and SE at some locations and months.
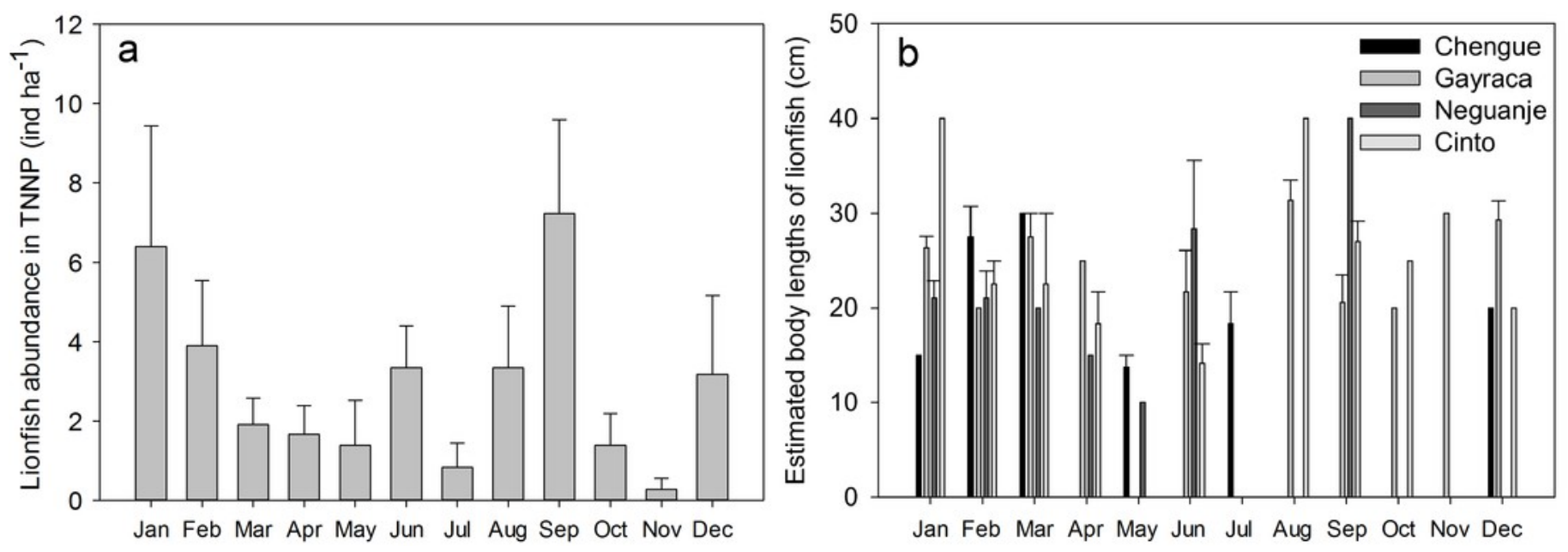


\section{Table 1 (on next page)}

Comparison of Pterois volitans abundance in Tayrona National Natural Park (TNNP) with worldwide reports on invaded and native habitats. 


\begin{tabular}{llll}
\hline Region and Year & $\begin{array}{l}\text { Habitat for } \\
\text { lionfish }\end{array}$ & $\begin{array}{l}\text { Reported abundance } \\
\left(\text { ind ha }^{-1}\right)\end{array}$ & Source \\
\hline $\begin{array}{l}\text { Chengue Bay (TNNP, Colombian } \\
\text { Caribbean), 2012 }\end{array}$ & invasive & $1.4 \pm 0.6$ & this study \\
$\begin{array}{l}\text { Gayraca Bay (TNNP, Colombian } \\
\text { Caribbean), 2012 }\end{array}$ & invasive & $4.9 \pm 1.3$ & this study \\
$\begin{array}{l}\text { Neguanje Bay (TNNP, Colombian } \\
\text { Caribbean), 2012 }\end{array}$ & invasive & $1.8 \pm 0.6$ & this study \\
$\begin{array}{l}\text { Cinto Bay (TNNP, Colombian } \\
\text { Caribbean), 2012 }\end{array}$ & invasive & $3.4 \pm 0.8$ & this study \\
$\begin{array}{l}\text { TNNP, Colombian Caribbean, 2012 } \\
\begin{array}{l}\text { New Providence, Bahamas, Western } \\
\text { Atlantic, 2008 }\end{array}\end{array}$ & invasive & $2.9 \pm 0.9$ & this study \\
$\begin{array}{l}\text { Coast off North Carolina, USA, } \\
\text { Western Atlantic, 2004 }\end{array}$ & invasive & $21.2 \pm 5.1$ & Green and Côté (2009) \\
$\begin{array}{l}\text { Coast off North Carolina, USA, } \\
\text { Western Atlantic, 2008 }\end{array}$ & invasive & 150 & Whitfield et al. (2007) \\
$\begin{array}{l}\text { Palau Archipelago, Western Pacific, } \\
\text { 2008 }\end{array}$ & native & 2.2 & Morris and Whitfield (2009) \\
\begin{tabular}{l} 
Gulf of Aqaba, Red Sea, 1997 \\
\hline
\end{tabular} & native & $\sim 80$ & Grubich et al. (2009) \\
\hline
\end{tabular}

